\title{
Domestic Violence and the Paradox of Post-Separation Mothering
}

\author{
Stephanie Holt*
}

School of Social Work \& Social Policy, University of Dublin, Trinity College, Dublin 2, Ireland

*Correspondence to Dr Stephanie Holt. E-mail: sholt@tcd.ie

\begin{abstract}
This paper reports selectively on findings from a mixed-methods study to consider the paradoxical post-separation position many women find themselves occupying when child contact necessitates the continued and mainly unmonitored presence of abusive men in their lives and the lives of their children (Holt, 2011). Having engendered blame and being held responsible for the exposure of their children to domestic abuse, mothers may find themselves resisting post-separation child contact and again engendering blame for daring to interfere with the father-child relationship-the same relationship they were charged with protecting their children from. Echoing Thiara and Humphreys's (2015) call for social worker practitioners to recognise that domestic abuse can continue even in the abuser's absence, this paper reflects on an issue of particular relevance to social work practitioners - that the continued presence of domestically abusive men, post separation, may compromise the child's recovery from the experience of domestic abuse due to continuing abuse and undermining of the maternal role and mother-child relationship.
\end{abstract}

Keywords: Post-separation contact, mothering through fear, gendered practice, childcentred assessment

Accepted: September 2016

\section{Introduction}

Scholarship on domestic abuse has until more recent times primarily concerned itself with the women's, as opposed to the mother's, experience of abuse, while the weight of empirical interest in parenting in this context has remained firmly on mothering (Humphreys and Absler, 2011). 
This discourse predominately reflects a 'deficit model of mothering' (Lapierre, 2008, p. 455), characterised by gendered notions of parenting, blame and responsibility. The focus on the mother pre separation, particularly on her role and responsibility as protector of her children from her abusive partner, is frequently cited as being accompanied by an intimation of blame, for not leaving this abusive partner sooner (Scourfield, 2003). The evidence further asserts that this insinuation of blame is delivered predominantly, but not exclusively, by child and family social workers who demonstrate little understanding of what leaving entails or indeed that leaving does not guarantee a cessation of her abusive experiences and the impact that continued abuse has on her post-separation mothering (Humphreys and Absler, 2011). Hallett's (1989) early observation that the majority of both clients and social workers are female is picked up on by Scourfield (2003, p. 149), who concludes that 'undeniably women social workers exert control over women clients'. A more recent study by Keeling and van Wormer (2012) explores this 'control' issue, drawing a parallel between the forms of coercion that women report social workers to employ and those employed by the abuser.

A simultaneous focus on the more central role that fathers have come to occupy in children's lives has led to many experts concluding that the absence of this role is damaging for children (Lamb, 2004; Perel and Peled, 2008). This perspective would suggest that supporting domestically abusive fathers to maintain post-separation contact with their children is important (Levin and Mills, 2003). Indeed, the dominant discourse across the globe contends that outcomes are more positive for children when relationships are sustained with both of their parents (Elizabeth et al., 2012). Featherstone and Peckover (2007, p. 189) argue, however, that father involvement needs to be 'located contextually' and that that context involves domestic abuse. The dominance of this discourse of father involvement is such that Kaganas and Day Sclater (2004, p. 1) surmise it has passed into the realms of 'incontestable truth', where it is 'almost impossible to conceive of a father who is harmful to his children unless he inflicts direct violence on them' (Elizabeth et al., 2012 , p. 52). Harne (2011, p. 65) argues that the belief that fathers are critically linked to children's welfare 'has overridden children and mothers right to protection' and has 'compromised their safety as a result'. Echoing this assertion while reflecting on the growth in initiatives aimed at engaging fathers who perpetuate domestic abuse, Featherstone and Fraser (2012) caution against the emphasis in these programmes on the welfare of the child as opposed to the women's safety. This ideology of involved fathering is central to an understanding of how post-separation mothering is experienced through the facility of child contact, where a prior history of domestic abuse exists. 
Post-separation child contact may be agreed informally by the family or may be court-ordered. While this may be a reasonably uncomplicated process that potentially is arranged and agreed in a seamless manner (Hester et al., 2000), the empirical evidence indicates that, for approximately 10-30 per cent of separating families, the process by which contact is agreed is an 'uphill battle' (Dunn et al., 2004) that is emotionally charged, problematic and potentially dangerous (Dunn et al., 2004; Saunders and Barron, 2003; Trinder, 2007). Guille (2004) is among a number of authors who draw attention to the complex, problematic and potentially dangerous risks associated with post-separation contact for children and their mothers, suggesting that these dangers are possibly greater than any potential value for those involved (Lessard et al., 2010). Having left their abusive partner, often under pressure from child and family social workers (Lapierre, 2010), this paper reports selectively on findings from a mixed-methods study to consider the paradoxical postseparation position many women find themselves occupying, when child contact facilitates the 'ongoing and often unmonitored presence of abusive men' (Holt, 2011, p. 327) in the lives of women and children. Having engendered blame and being held responsible for the exposure of their children to domestic abuse, mothers may find themselves resisting post-separation child contact and again engendering blame for daring to interfere with the father-child relationship-the same relationship they were charged with protecting their children from. Echoing Thiara and Humphreys (2015) call for social worker practitioners to recognise that domestic abuse can continue even in the abuser's absence, this paper reflects on an issue of particular relevance to social work practitioners - that the continued presence of domestically abusive men, post separation, may compromise the child's recovery from the experience of domestic abuse, due to re-traumatisation through the continuing abuse and undermining of the maternal role and mother-child relationship.

\section{Research review}

\section{Mothering and domestic violence}

Reflecting Jaffe et al.'s (2003, p. 29) contention that 'separation is not a vaccination against domestic violence', the empirical evidence attests that the abuse of the woman post separation not only continues, but may actually escalate to dangerous levels (Lessard et al., 2010; Radford et al., 1999).

Post-separation abuse of the mother is documented to include verbal and psychological abuse (Fish et al., 2009; Kirkwood, 1993), harassment, stalking, threats of violence (including death threats), physical and sexual assaults (Kaye et al., 2003) and threats or attempts of suicide 
(Parker et al., 2008). This abuse can be witnessed by children, who also may be implicitly and explicitly involved in the abuse of their mother. In agreement with Stanley (2011), it is important to establish that a woman's experience of parenting does not happen in a vacuity and that the threat or existence of domestic abuse creates a particular context within which the maternal role is carried out-a context that Douglas and Walsh (2010, p. 503) describe as defined by 'layers of difficulty'. This can have significant implications for the mother-child relationship and for the woman's experience of mothering. Lapierre (2010, p. 1435) concludes that domestic abuse produces a status quo that 'complicates women's mothering'.

Implicit in the discourse on pre-separation mothering in an environment of domestic abuse is a criticism, often reflected in social work practice (Elizabeth et al., 2010), of her parenting or mothering for exposing her children to this abuse alongside a simultaneous stark absence of social work holding the abuser responsible for his behaviour (Hester, 2011; Thiara and Humphreys, 2015). The dominant emphasis on the negative impact of this exposure on children stands in stark contrast to the secondary concern given to the importance of the mother-child relationship in both a protective and therapeutic capacity (Letourneau et al., 2007). This, Thiara and Humphreys (2015) consider, contributes to the barriers statutory social work has historically experienced in responding usefully to the needs of adult and child victims of domestic abuse (Humphreys and Absler, 2011). Simultaneously, minimal consideration has been given to the abusive actions of men and to their role as fathers in this regard (Harne, 2004, 2011; Holt, 2011), leading Humphreys (2010, p. 511) to conclude that children may be 'no safer' post separation where contact provides 'endless opportunities' for continued exposure to domestic abuse. The disappointing history of statutory social work to engage with what Brown et al. (2009) term 'ghost fathers' compounds both the risk and vulnerability of those victims post separation.

From the mother's perspective, the stress of enforced ongoing contact with their ex-partner may result in her becoming overwhelmed and withdrawing from her children at a time when she critically needs protection and support (Dunn et al., 2004). This is particularly significant given Leung's (2015) argument that the non-abusive parent-child relationship is the key protective resource for the child to draw on in their recovery from exposure to domestic abuse. The maternal parenting role, however, may be undermined 'where inappropriate behaviour is encouraged and rewarded' (Buckley et al., 2006, p. 23) or where the mother is blamed for the separation (Bancroft and Silverman, 2002). Having made efforts to protect herself and her children, often under pressure from child protection workers (Humphreys et al., 2011), she now finds that she cannot actually extricate herself from her relationship with this abusive man, as contact negates her chance of a fresh 'abuse-free' start (Kelly, 2009; 
Rhoades, 2002). Nor can she guarantee her children's safety and protection when the child protection surveillance lens has switched from viewing her ex-partner as abusive and dangerous for her children to one that holds the father-child relationship in high esteem (Rhoades, 2002).

With Buchanan et al. (2001) concluding from their research that children exposed to high levels of post-separation conflict are one of the most distressed groups of children in the population, it seems both relevant for social work practice and also reasonable from a child protection and welfare perspective to contest the 'incontestable truth' that Kaganas and Day Sclater (2004, p. 1) surmise to underpin the prevailing procontact discourse and explore the decision-making process in child contact.

\section{Contact: the decision-making process}

Hester (2011, p. 839) invites us to consider that the responses of a range of professionals involved in the protection and welfare of children to the issues of domestic abuse, child welfare and post-separation child contact are so diverse that they belong on three different planets, resulting in 'unintended fragmentation', with each operating within their own individual and unique history, language and law. Planet A, Hester (2011) calls 'Planet Domestic Abuse', where the focus is largely on adults, usually male perpetrators and female victims. The focus shifts on Planet B, otherwise known as 'Planet Child Protection', where the child and what is considered to be in their best interest become the centre of attention. Despite a wealth of evidence attesting to the fact that child contact can facilitate ongoing abuse of women and children, the underlying ethos of Planet C, 'Planet Child Contact', concerning the presumption of postseparation contact serves to delete the history of domestic abuse (Trinder et al., 2010).

Hester's (2011) model highlights a number of issues worth unpacking in this journey towards understanding how contact decisions are made when there is a history of domestic abuse. The first of these concerns the belief that domestic abuse ends with the termination of the parents' relationship and is not a significant feature of contact disputes. This is a prevailing and powerful myth, despite being challenged and unquestionably dismissed by the established bank of research evidence (Trinder et al., 2010). Notwithstanding the established correlation between domestic abuse and child abuse, and between post-separation contact and continued abuse, contact is rarely denied (Bailey-Harris et al., 1999; Coy et al., 2015). Instead, an almost universal judicial focus on looking towards the future rather than the past renders prior histories irrelevant, even where those histories involved abuse, severing the relationship between domestic abuse and its impact on children (Elizabeth et al., 2012; 
Harrison, 2006). Consequently, domestic abuse may not be viewed in either social work or legal domains as a child welfare issue and the parenting capacity of abusive men may be gauged without any consideration of their abusive behaviour (Elizabeth et al., 2012). This, of course, is premised on the assumption that positive outcomes for the child are dependent on contact with their father, minimising the potential consequence of domestic abuse and promoting the value of contact at any cost (Bradshaw et al., 1999; Harrison, 2006).

Second, a prevailing myth relates to Gardner's (1987) 'Parental Alienation Syndrome' (PAS), which considers that concerns expressed by mothers about their child's welfare and protection arising from contact with their father, are fabricated and spiteful. While this myth has been discredited under the weight of research evidence (Brown, 2006), remnants nonetheless appear to remain ingrained in practice. Gardner's PAS relied on a construction of women as 'bad mothers' - an image that is certainly replicated in the domestic abuse sphere, as Hester's (2011) model highlights, and indeed is a recurrent theme in the social work literature (Humphreys et al., 2011). Resistance to contact on behalf of the resident parent is subsequently deemed 'implacable hostility'; parents who do not agree and co-operate are viewed as acting inappropriately; and children resisting contact are considered to have been 'brainwashed' (Rhoades, 2002) because what other reason could there be for not wanting what is evidently in the child's best interests?

The question of why women resist contact is further explored by Reece (2006), who stresses the need to understand this resistance in the context of their experience of abuse, of fear for their own safety and their child's safety, as opposed to a simple explanation of resistance for resistance's sake. Resistance by mothers is not therefore understood by those involved in the decision-making process to arise from justifiable fear, but rather to be 'at best, trivial and at worst, spurious' (BaileyHarris et al., 1999, p. 120). Bailey-Harris et al.'s (1999) research with judges further noted that mothers who resisted contact were treated like badly behaved school children who needed to be made to behave like responsible adults. Returning to the three planets, Hester (2011, p. 850) cautions that the fundamental ethos of each planet focuses both social work and judicial involvement in different directions, creating what she concludes is a 'black hole that mothers and children may fall through'.

\section{Methodology}

As reported elsewhere (Holt, 2015), a two-phase mixed-methodological research design was utilised to investigate children's experience of postseparation contact with domestically abusive fathers. Two hundred and nineteen separated mothers who collectively had 449 children 
participated in Phase One. They were accessed through a national network of domestic abuse services in Ireland. The survey comprised two detailed questionnaires completed over the course of one month. One was completed by 147 mothers whose 317 children were, or had been, involved in post-separation contact with their fathers over the course of the twelve months preceding the completion of the questionnaire. A second survey was completed by seventy-two mothers regarding their 132 children who were not or had not been having contact over the same time frame. The surveys methodically collected data with respect to a number of variables concerned with recording the nature and extent of post-separation contact. Opportunities for optional qualitative comments were also provided, in addition to the required quantitative responses.

Analysis of the Phase One survey findings informed the design of Phase Two, which sought in-depth engagement with how contact was directly experienced by children, fathers, mothers and an array of professionals spanning child and family social work, the judiciary and professionals working in domestic abuse services. The main method for interviewing the children, mothers and professionals was focus groups while the fathers participated in individual interviews. The choice of interview format was informed by research guidance in this regard (Aubrey and Dahl, 2005; Buckley et al., 2007).

Participants included sixteen children and young people aged seven to twenty-four years of age; nine mothers; six fathers; and thirty legal, health, social work and social care professionals. With particular consideration for the emotional well-being of participants, the sampling criteria only included those children, young people, mothers and fathers where the parental relationship had ended a minimum of twelve months prior to engaging in the research. With consideration for the child's age and their developmental stage, an age benchmark of between seven and twenty-five years was applied. The sampling method employed for membership of the focus group was stratified so that each focus group reflected age and gender representation where that was possible and appropriate.

Preliminary access to the children and young people was enabled by the participating organisations and the consent of their parents was also obtained before the informed consent of the children and young people themselves was also secured. Motivated by Aubrey and Dahl's (2005) research, age-appropriate vignettes were specifically designed to stimulate discussion with the younger children. Interview schedules were designed for the interviews with the mothers, fathers and professionals based on a schema of thematic probes and questions.

Following the guidance on mixed-method sequential approaches (Creswell and Plano Clark, 2007), Phase One and Phase Two data-sets were linked, beginning with the analysis of each data-set using the techniques normally used in the analysis of that data (SPSS and NVivo). 
Each data-set was kept analytically separate from the other, with results from each of the respective data-sets combined at the interpretative stage of the research process. Ethical approval was granted at the outset of the research by the Children's Research Centre, Trinity College Dublin.

\section{Discussion of findings}

\section{The contact experience}

The fact that post-separation abuse is both a fear and an actuality for some women separating from abusive men, and particularly connected with contact, resounded clearly in this research. Concerns for their own welfare and protection directly related to post-separation contact were raised by 64 per cent of Phase One 'contact' mothers, by all of the nine women interviewed and by a number of their children.

Examples given by participating mothers of relentless efforts by men to maintain power and control over the family included constantly changing contact arrangements; arriving and collecting late, early or not at all; emotional blackmail and manipulation; unnecessary and unwanted daily telephone calls and texts; using contact to glean information from the child about the mother's activities; restricting contact between children and their mother during contact; and intransigence regarding arrangements for special events and the organisation of passports. Children also reflected on their exposure to this abuse, with one child, eleven-year-old Rachel, clearly connecting her mother's 'sadness' to incidents where her father calls her mother abusive names-names her younger sister then repeats.

The mother's responsibility for making contact safe for herself and her child was also evident in this research. Examples given included their lives being threatened at gun point by their ex-partner, their homes being threatened with arson and being stalked or intimidated. Campbell et al.'s (2007) research findings on the risks of severe and lethal violence associated with separation were also reflected in this present research:

He took a rusty hatchet out of the shed and came through the slide [patio] door at probably about half two in the morning. I was stripped off to me nude and made sit like that for the night, [toddler] woke up on me lap and he beating me into the face ... [I was] still awake at 11 o'clock the next morning, freezing from the cold coming in. The kids locked in the bedroom 'cause he wouldn't let them out. He was like a mad man-the things that happened that night with the child in the bedroom beside me (Tanya, mother).

Hardesty's (2002) assertion that stalking cases often involve men who cannot accept what they perceive as rejection when their partner leaves 
them, with women at risk of assaults that increase with severity and lethality, is also illustrated by the following quote: '[He] said "I'm going to smash you, nobody can have you"' (Survey respondent).

\section{Impact on the mother and on mothering}

Humphreys and Thiara's (2003) conclusion that separation results in intense feelings of loneliness for many women resonated to some degree in this present study. Nine-year-old Cathy saw herself and her two sisters as the only company her mother had, describing her mother as 'quite lonely 'cos none of them [extended family] will talk to us anymore'. Furthermore, Laing's (2006) contention that mothers may reconstruct their role as if they were a single parent, assuming complete responsibility for everything, permeated many of the interviews. Regarding child rearing and housework, nine-year-old Sara stated that 'Mum nearly does everything' - an experience some mothers found 'overwhelming': 'At times you'd like someone to help ... you'd love a break, but you don't know is them few hours Saturday worth the agro for to get a break from them' (Claire, mother).

Fear and vulnerability, which Jaffe and Crooks (2004) assert have the capacity to reduce a mother's ability to nurture and support her children, were closely related experiences for many of the women interviewed, who feared violent retribution for being strong enough to leave their abusive partners-a fear that was reinforced through child contact. This fear was not an isolated or disjointed experience, but was conversely something that pervaded their lives (Hardesty, 2002). Mullender et al. (2002) surmised that a combination of constant anxiety, abusive episodes and fear renders mothers exhausted and with reduced energy for their children.

Blame and responsibility emerged in many ways as flip sides of the same coin, with blame frequently couched in anger. Mothers talked about their children's anger at them 'for leaving them in it' (Peggy, mother), for taking them away from their father or for resisting reunification. Implicit in these dimensions of the separation and contact experience is the mother's sense of guilt and responsibility. Participating mothers blamed themselves for their child's exposure to the abuse and subsequently were blamed by fathers when children chose themselves not to engage in contact. In tandem with self-blame was an acute sense of failure, of a failed marriage and a sense of failed motherhood for not protecting her children more adequately: 'I kept thinking it must be my fault. To this day he says our marriage failed because of my upbringing. It was everybody else's fault but his' (Peggy, mother).

Mothers in this research expressed acute and conflicting feelings of responsibility, both for their child's protection and also for nurturing the 
father-child relationship. Mothers and children alike recalled social work involvement placing responsibility on the mother for the protection of the children, in the absence of holding the father accountable for the abuse he perpetrated:



Social work got involved. I do remember them giving Mam a hard time (Colette, twenty-four).

The focus went on his rights to access. Protection order still stands but father [was] never asked to address his violence to mother (Survey respondent).

The above accounts of blame, responsibility and perceived or accused failure in their mothering resonates the 'damned if you do and damned if you don't' dilemma that Lapierre (2008) asserts accompanies the 'deficient model of mothering', despite empirical evidence to the contrary provided by the research of Letourneau et al. (2007) and Levendosky et al. (2003). The uncertainty that seems to be part of the contact package left many women with an overwhelming sense of powerlessness (Radford et al., 1999). Women were unable to predict, first, whether or not their child's father would arrive for contact and, second, how that contact experience would transpire, resulting in a feeling of incapacitation regarding the welfare and protection of their children: 'It's like a never-ending cycle ... they could have a great day with him which would happen in a blue moon ... you've no control. It's not predictable' (Claire, mother).

Failure to achieve emotional and economic independence (Kelly, 2009) resulted for many mothers in deep-seated anger-anger at themselves for failing to succeed in their separated life just as they perceived they had failed in their married life, that they were still being controlled by their ex-partners and that their children continued to be negatively affected. Low self-esteem and damaged trust in their mothering abilities left them questioning their own judgements, their decisions and their parenting capacities.

All of the above had clear implications for women's physical and mental well-being. Similarly to the mothers in Radford and Hester's (2006) research, coping strategies included abusing alcohol and at times resulted in depression and reliance on psychiatric support in order to survive. Women also described fear-induced sleeplessness and physical and mental sickness:

When I feel low, I retreat back in, I close up. He always seems to put me back in a bad place. And then you wonder what was so wrong with you that you start blaming yourself. So you're kind of back in that vicious cycle (Claire, mother).

Long-term exposure to domestic abuse followed by post-separation contact and subsequent ongoing abuse has repercussions for mothering 
capacity and the resulting mother-child relationship, leading to what this research identified as 'the paradox of post-separation mothering'.

\section{The paradox of post-separation mothering}

I don't think seeing their father is a good idea because he is very manipulating, putting them on guilt trips and getting violent to me. So I dunno if I am doing the right thing. It goes against my grain because he is of no benefit to them. He can't spend quality time with them and I just don't see the point in the visits, they are not constructive, not helpful, not nurturing, not anything except annoying (Marian, mother).

The quote above from Marian highlights the conflicts many mothers expressed in this study; where they struggled with both innate and socially constructed mothering instincts that urged them to protect their children and similarly intrinsic drives towards supporting the father-child relationship. This was reflected in a vacillation between supporting the children's wish to end contact or supporting them through contact.

This sense of being 'caught between a rock and a hard place' resounded throughout this research, echoing Edleson and Williams (2007) and Elizabeth et al.'s (2010) finding that mothers felt they had no right to disrupt the father-child relationship by interfering in contact. The quandary mothers found themselves in involved concern for their own safety and perhaps their ongoing abuse in the context of contact, alongside their child's love for, and need to see, their father (Jaffe and Crooks, 2004). For others, the father's interaction with his children caused them to question the appropriateness of the contact arrangements for their child's welfare. These findings resonate with those of Kelly (2009, p. 294), who described her participants as caught in 'multiple binds': bound to the abuser and their children, to the role of mother and of partner; bound to the ideal and the reality of family life; caught in a 'classic Catch-22 at the intersection of their marginalized social, economic and legal positions and their conflicting emotions'.

Seery and Crowley's (2000, p. 101) reflections on women's 'emotion work' in the family, specifically the energy they expend towards fatherchild relationships, were also evident in this study. Encouraging and facilitating father-child contact, both implicitly by 'giving permission' to the non-resident parent to have an important role (Loar, 1998) and explicitly by involvement in transporting children and suggesting ideas for activities, are examples of this 'emotion work'. This was portrayed as particularly distressing and daunting by participating mothers who feared their ex-partners but felt unable to sever that adult relationship because of the father-child relationship.

Despite the experiences of frightening and abusive contact for many women in this study, their explicit support of father-child contact and 
continued attempts at what Seery and Crowley (2000) term 'gate-opening' challenge the 'gate-keeping' role mothers are more commonly accused of (Austin, 2011). The facility of father-child contact exposed these mothers to their previously abusive partners in a manner that induced fear - a fear of what might or could happen arising from their prior experiences. This fear enhanced their vulnerability, interrupted their recovery and compromised their mothering. As with previous research, for a significant number of mothers in this research, the fear of what might happen became a reality in which their post-separation lives mirrored their pre-separation lives in all but co-habitation (Kaye et al., 2003). This had clear implications for their identity as mothers, with questionable ramifications for their mothering capacity:

I don't know am I doing the right thing or not. The whole time I am questioning myself-was I right to leave him, were they better off then? Are they better off now? Would they be better off without him? I come up with different answers every-time and I wonder will I ever know or by then will it be too late. Sometimes I think I am the crappiest mother alive (Claire, mother).

As found elsewhere, the majority of mothers in this present study, initially at least, saw a clear value in continuing father-child contact and were actively involved in making that happen (Elizabeth et al., 2010; Radford et al., 1999). As with Edleson and Williams's (2007) research, the belief in the need for safety underscored the mothers' decision to facilitate contact: primarily their child's safety, with their own safety cited as a secondary concern. Women described the dual tasks of 'strategising' to maximise their own safety whilst simultaneously attentive to the safety and emotional welfare of their children as provoking many conflicting emotions (Kelly, 2009). In part, this concerned their own abusive relationship with their child's father, but it was also directly related to what some mothers perceived to be an abusive experience for their child. Despite those conflicting feelings, unambiguous maternal support for children's contact time with their father, couched in what Laing (2006) terms a 'child-focused' discourse, emerged clearly from this present study. This support was grounded in a concurrent belief that fatherchild contact was in their child's 'best interest'.

Previously constructed as problematic because of the child's exposure to their abuse of the mother, the findings from this research concur with Collier (2006), highlighting a combination of disappearing and disregarded histories of domestic and child abuse overshadowed by a potent perception of the child's need for continued paternal involvement: 'Judge ordered all children to have contact, even though incident [of physical abuse] with older son, Judge said "children need their father, he is the only one they have", (Survey respondent). 
As the above quote reflects, even where a father has been abusive to his child, the absence of the father in the child's life was considered by the relevant professionals involved to be more harmful than the experience of his abuse. Despite their own abusive relationship and without exception, participating mothers considered the role of the father important in their child's life. Similarly to Radford and Hester's (2006) findings, this sometimes involved considerable effort on their part, involving both physical work and, as Seery and Crowley (2000) considered, 'emotion work' to ensure contact happened. This not only prevented them from severing their connection to their abusive ex-partner, but also, for over two-thirds of mothers completing the survey in Phase One and all Phase Two mothers, resulted in the continuation of the abuse they sought to end. The focus in family law on expecting women to overcome their fear of violence as opposed to holding abusive men accountable (Hester, 2011) simultaneously renders the behaviour of abusive men invisible whilst failing to address key safety and welfare issues for the child (Mandel, 2010). This led to one mother analogising her life to the popular movie Groundhog Day, as the following quote poignantly illustrates:

I thought that by leaving him and doing the 'right thing' that I could make good the bad things that had happened that me kids saw. But it's like groundhog day gone wrong 'cos I can't change nothing ... I can't stop the movie and change the script to make it all go away 'cos it's still the same. I thought leaving would make a difference but it hasn't. The only difference is we don't live together (Marian, mother).

\section{Conclusion}

The incongruent drive to support what they perceive as inappropriate contact, along with their innate need to protect their children from harm, often results in allegations of gate-keeping and mendacious mothering. It also mirrors, to a degree, a dual and simultaneous construction of motherhood as both 'natural' but also deeply problematic and in need of scrutiny and regulation (Collier, 2001). Indeed, such is the strength of the ideology of motherhood that mothers are held, and indeed hold themselves, responsible for the welfare and protection of their children, whilst simultaneously being blamed, and indeed blaming themselves, when that does not happen (Farmer and Boushel, 1999).

This study highlighted that domestic abuse was consistently considered an adult affair-a feature of the adult relationship which was no longer a child welfare and protection concern, as opposed to a feature of personality, psychology, social skill or indeed parental deficit. While research has consistently highlighted the risks for women and children associated with post-separation contact with a domestically abusive man 
(Radford and Hester, 2006), post-separation contact is nonetheless considered the 'preferred' vehicle for continued father involvement. This 'uncritical assumption' of contact (Lessard et al., 2010, p. 333) reflecting a complete 'lack of understanding of the distinct possibility of unfit fathering practices' (Hart, 2009, p. 2003) is considered by Wallbank (2010) as dangerous. Prioritising the father's role in the post-separation family simultaneously displaces any consideration of women's safety needs (Thiara and Gill, 2012) whilst conflating 'the welfare of children with the needs of their fathers' (Morrison and Washoff, 2012, p. 714). It is noteworthy and somewhat paradoxical that the relationship that dominates the debate in child contact is the one that technically does not exist anymore- that of the separated parents-whilst the best interest of the child becomes subsumed under an argument about truth and lies, blame and responsibility, rights and welfare. The outcome of these debates and tensions is that the current construction of post-separation family life supports the ongoing and often unmonitored involvement of domestically abusive men in children's lives (Holt, 2011), based on the belief that post-separation contact serves children's rights and is in their best interests. The evidence from the study on which this paper is drawn challenges this belief. While the traditional response has been to focus responsibility for child protection and for the father-child relationship on the mother, this paper concludes by calling for a shift in the focus from what mothers and children are or are not doing to the father's behaviour. This demands that social work practitioners, particularly those with a statutory role, explicitly recognise what Thiara and Humphreys (2015) term the 'shadow' that abusive men continue to cast over the mother-child relationship by focusing on the reality rather than the rhetoric of post-separation fathering. This is of particular relevance if we accept Leung's (2015) assertion that the non-abusive parent-child relationship is the most important protective resource for the child to draw on in their recovery from exposure to domestic violence. As this paper has argued, ongoing abuse by the father, even in his absence, may continue to challenge her parenting capacity and the mother-child relationship.

Positioning the findings from this study against the backdrop of what Humphreys and Absler (2011) conclude is a historical failure of statutory social work to respond effectively to the needs to women and children experiencing domestic abuse, there are some immediate implications for social work practice. This paper echoes Featherstone and Peckover's (2007, p. 181) contention that 'taking violent men seriously as fathers and father figures' is a precursor to supporting women and children, particularly if we accept Keeling and van Wormer's (2012, p. 1355) assertion that social work is critically positioned to respond to the needs of women experiencing domestic abuse. This, however, demands that social work engages unequivocally with an appreciation that separation is not a 'vaccine' against domestic violence 
(Jaffe et al., 2003, p. 29) and that the vulnerability of women and children can continue post separation through the facility of contact. This is critical for this profession's statutory obligation to respond to the welfare and protection needs of vulnerable children and families to be realised.

\section{Acknowledgements}

The author wishes to acknowledge the three-year studentship awarded by the Health Research Board which funded the completion of this doctoral study.

\section{References}

Aubrey, C. and Dahl, S. (2005) 'That child needs a good listening to! Reviewing effective interview strategies', Journal of Education, 35, pp. 99-119.

Austin, W. G. (2011) 'Parental gatekeeping in custody disputes', American Journal of Family Law, 25(4), pp. 148-53.

Bailey-Harris, R., Barron, J. and Pearce, J. (1999) 'From utility to rights? The presumption of contact in practice', International Journal of Law, Policy and the Family, 13(2), pp. 111-31.

Bancroft, L. and Silverman, J. G. (2002) The Batterer as Parent: Addressing the Impact of Domestic Violence on Family Dynamics, New York, Sage.

Bradshaw, J., Stimson, C., Williams, J. and Skinner, C. (1999) Absent Fathers, London, Routledge.

Brown, L., Callahan, M., Strega, S., Walmsley, C. and Dominelli, L. (2009) 'Manufacturing ghost fathers: The paradox of father presence and absence in child welfare', Child \& Family Social Work, 14, pp. 25-34.

Brown, T. (2006) 'Child abuse and domestic violence in the context of parental separation and divorce: New models of intervention', in Humphreys, C. and Stanley, N. (eds), Domestic Violence and Child Protection: Directions for Good Practice, London, Jessica Kingsley, pp. 155-68.

Buchanan, A., Hunt, J., Bretherton, H. and Bream, V. (2001) Families in Conflict: Perspectives of Children and Parents on the Family Court Welfare Service, Bristol, The Policy Press.

Buckley, H., Holt, S. and Whelan, S. (2007) 'Listen to me! Children's experiences of domestic violence', Child Abuse Review, 16(5), pp. 296-310.

Buckley, H., Whelan, S. and Holt, S. (2006) Listen to Me! Children's Experiences of Domestic Violence, Dublin, The Children's Research Centre, Trinity College Dublin.

Campbell, J. C., Glass, N., Sharps, P., Laughon, K. and Bloom, T. (2007) 'IPH: Review and implications of research and policy', Trauma, Violence and Abuse, 8(3), p. 246.

Collier, R. (2001) 'A hard time to be a father? Reassessing the relationship between law, policy, and family (practices)', Journal of Law \& Society, 28(4), pp. 520-45.

Collier, R. (2006) 'The outlaw fathers fight back : Fathers rights groups and the politics of family law reform - Reflections on the UK experience', in Collier, R. and 
Sheldon, S. (eds), Fathers' Rights Activism and Law Reform in Comparative Perspective, Oxford, Hart Publishing, pp. 53-77.

Coy, M., Scott, E., Tweedale, R. and Perks, K. (2015) “"It's like going through the abuse again": Domestic violence and women and children's (un)safety in private law contact proceedings', Journal of Social Welfare and Family Law, 37(1), pp. $53-69$.

Creswell, J. W. and Plano Clark, V. L. (2007) Designing and Conduction Mixed Methods Research, Thousand Oaks, CA, Sage.

Douglas, H. and Walsh, T. (2010) 'Mothers, domestic violence and child protection', Violence Against Women, 16(5), pp. 489-508.

Dunn, J. H., Flory, B. E. and Berg-Weger, M. (2004) 'An exploratory study of supervised access and custody exchange services: The children's experience', Family Court Review, 42(1), pp. 60-73

Edleson, J. L. and Williams, O. J. (2007) Parenting by Men Who Batter: New Directions for Assessment and Intervention, New York, Oxford University Press.

Elizabeth, V., Gavey, N. and Tolmie, J. (2010) 'Between a rock and a hard place: Resident mothers and the moral dilemmas they face during custody disputes', Feminist Legal Studies, 18, pp. 253-74.

Elizabeth, V., Gavey, N. and Tolmie, J. (2012) 'The gendered dynamics of power in disputes over the postseparation care of children', Violence Against Women, 18(4), pp. $459-81$.

Farmer, E. and Boushel, M. (1999) 'Child protection policy and practice: Women in the front line', in Watson, S. and Doyal, E. (eds), Engendering Social Policy, Buckingham, Open University Press, pp. 84-101.

Featherstone, B. and Fraser, C. (2012) 'Working with fathers around domestic violence: Contemporary debates', Child Abuse Review, 21(4), pp. 255-63.

Featherstone, B. and Peckover, S. (2007) 'Letting them away with it: Fathers, domestic violence and child welfare', Critical Social Policy, 27(2), pp. 181-202.

Fish, H., McKenzie, M. and MacDonald, H. (2009) Bad Mothers and Invisible Fathers: Parenting in the Context of Domestic Violence, Victoria, Domestic Violence Resource Centre.

Gardner, R. A. (1987) The Parental Alienation Syndrome and the Differentiation between False and Genuine Child Sex Abuse, Cresskill, NJ, Creative Therapeutics.

Guille, L. (2004) 'Men who batter and their children: An integrated review', Aggression and Violent Behaviour, 9(2), pp. 129-63.

Hallett, C. (1989) 'The gendered world of the social services department', in Hallett, C. (eds), Women and Social Services Departments, Hemel Hempstead, Harvester Wheatsheaf.

Hardesty, J. L. (2002) 'Separation assault in the context of post-divorce parenting: An integrative review of the literature', Violence Against Women, 8(5), pp. 597-625.

Harne, L. (2004) 'Childcare, violence and fathering: Are violent fathers who look after their children likely to be less abusive?', in Klein, R. and Wallner, B. (eds), Gender, Conflict and Violence, Vienna, Studien-Verlag.

Harne, L. (2011) Violent Fathering and the Risks to Children: The Need for Change, Bristol, The Policy Press.

Harrison, C. (2006) 'Damned if you do and damned if you don't: The contradictions between private and public law', in Humphreys, C. and Stanley, N. (eds), 
Domestic Violence and Child Protection: Directions for Good Practice, London, Jessica Kingsley, pp. 137-54.

Hart, A. S. (2009) 'Children's needs compromised in the construction of their "best interests", Women's Studies International Forum, 33, pp. 196-205.

Hester, M. (2011) 'The three planet model: Towards an understanding of contradictions in approaches to women and children's safety in contexts of domestic violence', British Journal of Social Work, 41, pp. 837-53.

Hester, M., Pearson, C. and Harwin, N. (2000) Making an Impact: Children and Domestic Violence, a Reader, London, Jessica Kingsley Publications.

Holt, S. (2011) 'Domestic abuse and child contact: Positioning children in the decision-making process', Child Care in Practice, 17(4), pp. 327-46.

Holt, S. (2015) 'Post-separation fathering and domestic abuse: Challenges and contradictions', Child Abuse Review, 24(3), pp. 210-22.

Humphreys, C. (2010) 'Crossing the great divide: Response to Douglas and Walsh', Violence Against Women, 16(5), pp. 509-15.

Humphreys, C. and Absler, D. (2011) 'History repeating: Child protection responses to domestic violence', Child \& Family Social Work, 16, pp. 464-73.

Humphreys, C. and Thiara, R. K. (2003) 'Neither justice nor protection: Women's experience of post-separation violence', Journal of Social Welfare and Family Law, 25(3), pp. 195-214.

Humphreys, C., Thiara, R.K. and Skamballis, A. (2011) 'Readiness to Change: Mother-Child Relationship and Domestic Violence Intervention', British Journal of Social Work, 41, pp. 166-84.

Jaffe, P. G. and Crooks, C. V. (2004) 'Partner violence and child custody cases', Violence Against Women, 10(8), pp. 917-34.

Jaffe, P. G., Lemon, N. K. D. and Poisson, S. E. (2003) Child Custody \& Domestic Violence: A Call for Safety and Accountability, Thousand Oaks, Sage Publications.

Kaganas, F. and Day Sclater, S. (2004) 'Contact disputes: Narrative constructions of "good" parents', Feminist Legal Studies, 12(1), pp. 1-27.

Kaye, M., Stubbs, J. and Tolmie, J. (2003) Negotiating Child Residence and Contact Arrangements against a Background of Domestic Violence, Nathan, Australia, Socio and Legal Centre, Griffith University.

Keeling, J. and van Wormer, K. (2012) 'Social worker interventions in situations of domestic violence: What can we learn from survivors' personal narratives?', British Journal of Social Work, 42(7), pp. 1354-70.

Kelly, U. (2009) "I'm a mother first": The influence of mothering in the decisionmaking processes of battered immigrant Latino women', Research in Nursing \& Health, 32(3), pp. 286-97.

Kirkwood, C. (1993) Leaving Abusive Partners: From the Scars of Survival to the Wisdom for Change, London, Sage Publications.

Laing, K. (2006) 'Doing the right thing: Cohabiting parents, separation and child contact', International Journal of Law, Policy and the Family, 20(2), pp. 169-80.

Lamb, M. E. (ed.) (2004) The Role of the Father in Child Development, 4th edn, New York, John Wiley \& Sons.

Lapierre, S. (2008) 'Mothering in the context of domestic violence: The pervasiveness of a deficit model of mothering', Child and Family Social Work, 13(4), pp. 454-63.

Lapierre, S. (2010) 'More responsibilities, less control: Understanding the challenges and difficulties involved in mothering in the context of domestic violence', British Journal of Social Work, 40, pp. 1434-51. 
Lessard, G., Flynn, C., Turcotte, P., Damant, D., Vezina, J. F., Godin, M. F., Paradis, F., Delisle, R., Alcedo, Y., Juneau, L., Rock, L. and Rondeau-Cantin, S. (2010) 'Child custody issues and co-occurrence of intimate partner violence and child maltreatment controversies and points of agreement amongst practitioners', Child \& Family Social Work, 15, pp. 492-500.

Letourneau, N. L., Fedick, C. B. and Willms, J. D. (2007) 'Mothering and domestic violence: A longitudinal analysis', Journal of Family Violence, 22(8), pp. 649-59.

Leung, L. (2015) 'The effects on children of witnessing violence: Implications for social work practice', Asia Pacific Journal of Social Work and Development, 25(2), pp. 68-79.

Levendosky, A. A., Huth-Bocks, A. C., Shapiro, D. L. and Semel, M. A. (2003) 'The impact of domestic violence on the maternal-child relationship and preschool-age children's functioning', Journal of Family Psychology, 17(3), pp. 275-87.

Levin, A. and Mills, L. G. (2003) 'Fighting for child custody when domestic violence is an issue: Survey of state laws', Social Work, 48(4), pp. 463-71.

Loar, L. (1998) 'Making visits work', Child Welfare, 77(1), pp. 41-58.

Mandel, D. (2010) 'Child welfare and domestic violence: Tackling the themes and thorny questions that stand in the way of collaboration and improvement of child welfare practice', Violence Against Women, 16(5), pp. 530-6.

Morrison, F. and Washoff, F. (2012) 'Child contact centers and domestic abuse: Victim safety and the challenge to neutrality', Violence Against Women, 18(6), pp. 711-20.

Mullender, A., Hague, G., Iman, U., Kelly, L., Malos, E. and Regan, L. (2002) Children's Perspectives on Domestic Violence, London, Sage.

Parker, T., Rogers, K., Collins, M. and Edleson, J. E. (2008) 'Danger zone: Battered mothers and their families in supervised visitation', Violence Against Women, 14(11), pp. 1313-25.

Perel, G. and Peled, E. (2008) 'The fathering of violent men: Constriction and yearning', Violence Against Women, 14(4), pp. 457-82.

Radford, L. and Hester, M. (2006) Mothering through Domestic Violence, London, Jessica Kingsley Publications.

Radford, L., Sayer, S. and AMICA (1999) Unreasonable Fears? Child Contact in the Context of Domestic Violence: A Survey of Mothers' Perceptions of Harm, Bristol, Women's Aid Federation of England.

Reece, H. (2006) 'UK women's groups' child contact campaign: "So long as it is safe"', Child and Family Law Quarterly, 18(4), pp. 538-61.

Rhoades, H. (2002) 'The "no contact mother": Reconstructions of motherhood in the era of the "new father", International Journal of Law, Policy and the Family, 16(1), pp. 71-94.

Saunders, H. and Barron, J. (2003) Failure to Protect? Domestic Violence and the Experiences of Abused Women and Children in the Family Courts, Bristol, WAFE.

Scourfield, J. (2003) Gender and Child Protection, London, Palgrave MacMillan.

Seery, B. L. and Crowley, M. S. (2000) 'Women's emotion work in the family: Relationship management and the process of building father-child relationships', Journal of Family Issues, 21(1), pp. 100-27.

Stanley, N. (2011) Children Experiencing Domestic Violence: A Research Review, Dartington, Research in Practice. 
Thiara, R. K. and Gill, A. (2012) Domestic Violence, Child Contact and PostSeparation Violence: Issues for South Asian and African-Caribbean Women and Children, NSPCC.

Thiara, R. V. and Humphreys, C. (2015) 'Absent presence: The ongoing impact of men's violence on the mother-child relationship', Child \& Family Social Work Advance Access published January 5, 2015, 10.1111/cfs.12210.

Trinder, L. (2007) 'Dangerous dads and malicious mothers: The relevance of gender to contact disputes', in Maclean M. (ed.), Parenting after Partnering: Containing Conflict after Separation, Oxford, Hart Publishing, pp. 81-94.

Trinder, L., Firth, A. and Jenks, C. (2010) "'So presumably things have moved on since then?" The management of risk allegations in child contact dispute resolution', International Journal of Law, Policy and the Family, 24(1), pp. 29-53.

Wallbank, J. (2010) '(En)gendering the fusion of rights and responsibilities in the law of contact', in Wallbank, J., Choudhry, S. and Herring, J. (eds), Rights, Gender and Family Law, London, Routledge, Chapter 5. 